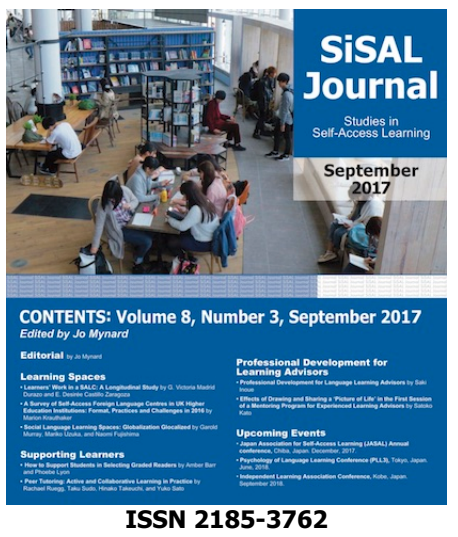

Studies in Self-Access Learning Journal

http://sisaljournal.org

\title{
How to Support Students in Selecting Graded
} Readers

Amber Barr, Kanda University of International

Studies, Chiba, Japan

Phoebe Lyon, Kanda University of International

Studies, Chiba, Japan

Corresponding author: barr-a@kanda.kuis.ac.jp

Publication date: September, 2017.

\section{To cite this article}

Barr, A., \& Lyon, P. (2017). How to support students in selecting graded readers. Studies in Self-Access Learning Journal, 8(3), 247-254.

\section{To link to this article}

http://sisaljournal.org/archives/sep17/barr_lyon

This article may be used for research, teaching and private study purposes. Please contact the authors for permission to re-print elsewhere.

Scroll down for article 
SiSAL Journal Vol. 8, No. 3, September 2017, 247-254.

\title{
How to Support Students in Selecting Graded Readers
}

Amber Barr, Kanda University of International Studies, Chiba, Japan

Phoebe Lyon, Kanda University of International Studies, Chiba, Japan

\begin{abstract}
Learner autonomy, and giving students the ability to select their own learning materials as a way to encourage them to take charge of their own learning, is now a major focus in education (Ellis \& Sinclair, 1989). However, students may not always feel confident making selections that were once made by their classroom teachers. The authors analyzed data from student surveys to determine possible factors that contribute to and influence students' graded reader selections. Results indicate that although some learners are able to make selections that meet their expectations, there are almost as many who are struggling to do so. In this report, the authors' aim is to offer suggestions as to how learners can be assisted to improve success in graded reader selection.
\end{abstract}

Keywords: extensive reading, self-regulated reading, autonomous readers, self-access learning center, learner autonomy

Extensive reading, or graded reading, is an important reading component for learners of additional languages. It allows for them to read a variety of genres, read large amounts of simple text within their current reading ability and for them (as opposed to the teacher) to choose their own material (Waring, 2000). The latter is important because encouraging learner autonomy through giving students the opportunity to select their own learning (reading) materials assigns students an active role in their learning process (Ellis \& Sinclair, 1989). However, choosing books can be daunting and students may often feel overwhelmed by the choices they are faced with. Furthermore, it is not always apparent how learners independently approach the task. The purpose of this report is to draw upon some preliminary research investigating how students select learning materials in order to help them to do so more efficiently.

\section{Literature Review}

Extensive reading is beneficial for learners since it allows them to meet language in a natural context, helps them to develop reading fluency and speed, assists with vocabulary attainment and has been shown to increase learner motivation and enjoyment of reading (ERF, 2011). Furthermore, Day and Bamford (2002) state that by allowing 
SiSAL Journal Vol. 8, No. 3, September 2017, 247-254.

learners to select materials that they want to read at their own ability level and that is of interest to them, learners are able to also increase their reading confidence. However, Waring (2000) states that in order for reading fluency and confidence to develop, learners need to read at or below their comfort level. Since selecting material may prove to be a daunting task, Day and Bamford (2004) recommend that learners use books or magazines that have been specifically written for language learners at different ability levels. Graded readers are therefore a suitable choice for language learners. Thus, extensive reading is often referred to as graded reading (Waring, 2000).

According to the ERF (Extensive Reading Foundation), students are best at judging their own comfort zone with respect to their level (2011). In fact, in literature showing how graded readers have been implemented into university level reading/writing courses in Japan, studies have often focused on the need for learners to make autonomous choices (Cheetham, Elliot, Harper, \& Sato, 2017; Harrold, 2013; O’Loughlin, 2012). Harrold's (2013) study indicated that when students self-selected books, they tended to enjoy them more than the class sets that had previously been assigned by their classroom teachers. However, even after being given an orientation to graded readers, when given the power to choose, it remains unclear how learners make decisions when they selfselect books or how they make subsequent choices. This appears to be an important area to investigate.

\section{Background}

Several years ago, an extensive reading program was introduced into the English and International Communications Department curriculums at a private Japanese university to help students become more autonomous readers. After an orientation to graded readers in 2015, we (the authors - two teachers of the course) asked students in three freshman classes to choose their own graded readers. We limited the students' choices to graded readers for the following reason: editors and publishers control the vocabulary and grammar that readers will be exposed to, with higher frequency vocabulary and a close range of grammar at low levels and lower frequency words and more complex grammar at higher levels (Lake \& Holster, 2014). The importance of selecting a level that students felt comfortable with was stressed to students in all three classes since it is unlikely that learners will develop into fluent readers with selections 
SiSAL Journal Vol. 8, No. 3, September 2017, 247-254.

that are above their current ability level (Waring, 2000). Students in all three classes were required to self-select a new book at least every two weeks for a total of five books. Waring (2000) and Nation (2009) suggest that this is a good timeframe in order for students to receive enough exposure to sustained reading and repetition of language. To determine how students felt about the book selections that they were making, students were asked to complete pre- and post-reading questions.

\section{How Students Viewed Graded Readers}

Responses to the research questions (see Appendix) indicated that students enjoyed the books for several reasons: the books were interesting, easy to summarize, an enjoyable genre, an appropriate level, or funny, they had an unpredictable ending or touching scenes, or the students learned new information. Similarly, there were many reasons given for books that the students did not enjoy: the books were too difficult, too easy, dark, too long, too short, or not like the students had expected (or not like the movie), or had disturbing content, a predictable ending, or shallow content.

\section{How Students Made Subsequent Material Choices}

Whereas most responses indicated that many students were aware of factors to consider in making a selection that might better meet their expectations, some responses indicated that learners were unsure of how to improve their choices.

Examples of criteria that students indicated they would consider when making subsequent choices were choosing a higher or lower level, trying a new genre, choosing based on a friend/ learning advisor/ teacher recommendation, or making a selection based on a story that they were already familiar with or on a movie that they had seen. A unique idea employed by one student was to look for a popular book based on how many times it had been borrowed. This approach was taken after two disappointing previous decisions. In this instance, the student liked the book and, more importantly, had found a suitable level.

Unfortunately, students did not always take their own advice and ignored the criteria they had specified for themselves when making their next selection. One student almost always commented that they would look at the blurb/cover for their next book selection. However, the student continued to base their choices on familiar stories, 
SiSAL Journal Vol. 8, No. 3, September 2017, 247-254.

movies they had seen or on friend recommendations. This student's expectations were never really met; having finally decided to review the cover and read the blurb for the final book they chose, they found the book to be a good level. Unfortunately, they also commented that it was too short.

Another student indicated that for a subsequent selection they would choose a specific genre, but they instead chose a book based on a friend's recommendation. This student was ultimately dissatisfied with the level of the book. Surprisingly, it seemed that when students chose books that were recommended (either by a friend, classmate, teacher or learning advisor), results were mixed when it came to how the selection met their expectations. The books were either interesting and a good level match, or were too challenging. This indicates that choosing a book requires more consideration than just selecting one because it was recommended, once again showing the possibility that students are not necessarily aware of their personal interests and levels. These are clearly points that need to be highlighted to students.

Although students were given the option to stop reading and select a new book per cycle if they were not happy with their choices, few students took advantage of this. Abandoning a book if it is either too difficult or not of interest is an important aspect of self-regulated learning (Lake \& Holster, 2014). Since there was a question on the survey that related to this, and there were classroom reminders, it is unfortunate that students who were not making choices that met their expectations did not take advantage of this option more often. This is an option that could be further reinforced.

\section{Developing an Awareness of How to Choose Materials}

The results varied as to when students began making choices that consistently met their expectations. Students that were successful throughout the selection process often looked at the title, read the summary and made their selections based on genre. Students that were mostly successful with only a single unsuccessful choice midway through either quickly realized their dissatisfaction and chose a new book to read instead or were able to return to making successful selections with their next books. They often did this by returning to earlier criteria they had used, notably, reading the blurb and checking the level. 
SiSAL Journal Vol. 8, No. 3, September 2017, 247-254.

It should be noted that students who were able to make the transition from choices that did not meet their expectations to ones that did accomplished this by their third choice. For those learners who were only starting to make more successful choices toward the end of the semester, it was clear from their survey responses that it was only at this late point that they started looking at book features such as the blurb or level. Although they had been through an orientation, some students did not take heed until this late stage.

Students that were inconsistent in meeting their expectations often struggled with choosing the appropriate level, mostly oscillating between being too challenging or too easy. Other reasons for choices not meeting expectations were that choices were 'not what they had expected (i.e. not like the movie), too predictable, or shallow'. Furthermore, students whose choices did not meet their expectations typically made their

selections based on the title, the picture on the front cover and recommendations, but only occasionally read the blurb and/or considered the level. One exception was a student who consistently read the blurb and checked the level, but was still unable to make choices that met their expectations. The student's challenge was finding a genre in the graded readers that suited their interest.

Although some students were able to delve into multiple genres with success, it seemed that they were perhaps more aware of the level that was comfortable for them and the subjects that interested them. Unfortunately, for many of the learners who chose from multiple genres, it appeared that they were not considering levels; therefore, their feedback often indicated that the book they had chosen was an inappropriate level. This would indicate that students need more assistance/ reminders when determining the levels and genres that are most suitable for them.

\section{Interventions for Helping Students to Make Effective Choices}

We believe that it would be beneficial to review book elements (e.g. level, title, genre, the blurb) in class, if not prior to each and every book selection that students make, at least periodically. Furthermore, if students in classes that have undergone an orientation to selecting graded readers are struggling with making successful choices, it can only be assumed that students who have not had such an orientation might also struggle, perhaps more so. Consequently, it might be beneficial to have information 
SiSAL Journal Vol. 8, No. 3, September 2017, 247-254.

available in the graded reader areas in SALCs and libraries that highlights important factors for selecting graded readers such as the genre, reading the blurb and reading the first page to check the level. Additional signs could be posted that clearly highlight the level of books, taking into consideration the differences often found between the different publishing houses, as well as signs reminding learners to ask SALC staff for advice when selecting a book. SALC staff could help learners think more carefully about what they need to consider when selecting a book. Another important role for SALC advisors, along with the classroom teachers, is to stress the importance of taking the time to review books, even if a particular book has been recommended or is famous/familiar.

\section{Conclusion}

Although students tend to prefer making reading choices when it comes to extensive reading, it is clear that selecting a book that matches one's expectations is not an easy task. Whilst some learners are able to immediately make successful selfselections, there are some learners who struggle and who are not as aware of their needs as a learner. It would benefit all learners making book selections to be able to refer to an easily accessible guide each and every time they make selections. Having one close at hand in the relevant section of the SALC or library would be useful. Learners clearly need added guidance and constant reinforcement on the path to becoming autonomous readers.

\section{Notes on the contributors}

Amber Barr is a Senior Lecturer at Kanda University of International Studies, Japan. Her main research interests are extensive reading and learner autonomy.

Phoebe Lyon is a Principal Lecturer for Curriculum and Assessment at Kanda University of International Studies, Japan. Her research interests include learner autonomy, materials development and assessment. 
SiSAL Journal Vol. 8, No. 3, September 2017, 247-254.

\section{References}

Cheetham, C., Elliot, M., Harper, A., \& Sato, M. (2017). Accessibility and the promotion of autonomous EFL reading. Studies in Self-Access Learning Journal, 8(1), 4-22. Retrieved from http://sisaljournal.org/archives/mar17/cheetham et at

Day, R., \& Bamford, J. (2002). Top ten principles for teaching extensive reading. Reading in a Foreign Language, 14(2), 136-141. Retrieved from http://nflrc.hawaii.edu/rfl/October2002/day/day.html

Day, R., \& Bamford, J. (Eds.) (2004). Extensive reading activities for teaching language. Cambridge, UK: Cambridge University Press.

Ellis, G., \& Sinclair, B. (1989). Learning how to learn English: A course in learner training. Cambridge, UK: Cambridge University Press.

ERF. (2011). The Extensive Reading Foundation's guide to extensive reading. Retrieved from www.erfoundation.org

Harrold, P. (2013). The design and implementation of an extensive reading thread in an undergraduate foundational literacies course. In S. Miles \& M. Brierley (Eds.), Extensive reading world conference proceedings, 2013 (pp. 225-231). Retrieved from http://keera.or.kr/wp-content/uploads/2012/09/ERWC2Proceedingsnew.pdf\#page $=230$

Lake, J., \& Holster, T. (2014). Developing autonomous self-regulated readers in an extensive reading program. Studies in Self-Access Learning Journal, 5(4), 394403. Retrieved from https://sisaljournal.org/archives/dec14/lake holster/

Nation, P. (2009). Teaching ESL/EFL reading and writing. New York, NY: Routledge.

O’Loughlin, R. (2012). Integrating learner autonomy into the design of a reading curriculum. In M. Hobbs \& K. Dofs (Eds.), ILAC Selections: 5th Independent Learning Association Conference 2012. Christchurch, New Zealand: Independent Learning Association.

Waring, R. (2000). The 'why' and 'how' of using graded readers. Tokyo, Japan: Oxford University Press. 
SiSAL Journal Vol. 8, No. 3, September 2017, 247-254.

\section{Appendix}

\section{Student Reflection Questions}

1. Why did you choose the book? Explain.

Q1, なぜその本を選んだのですか? 理由を説明しなさい

2. In which ways did this book meet or not meet your expectations? Explain.

Q2. どんな意味でこの本はあなたの期待に応え（あるいは期待を裏切り）ました か? 説明しなさい。

3. Did you start a book that you didn't finish? If yes, why didn't you finish that book?

Q3, 本を最後まで読み終えずに終わりましたか?もしそうならば、その理由はな んですか?

4. What will you consider when choosing the next book?

Q4, 次の本を選ぶ際には、どこに着目しますか? 